\title{
Two Pairs of Tricks: Ulysses and Guido in Dante's Inferno XXVI-XXVII
}

Among the characters whom Dante meets in Hell, some are presented so sympathetically that many critics maintain that the poet chose to dwell, not on the character's vice, but on some more admirable, or otherwise appealing, quality. To such readers it seems that there is no trace of heresy in the words or deeds of Farinata, no hint of sodomy in the character of Brunetto Latini, and no indication that in Hell Ulysses is still a counsellor of fraud.

The issues are most sharply delineated in the case of Ulysses because they have been clarified, though not resolved, by a seemingly endless debate, which can be briefly summarized. Virgil and the Pilgrim find Ulysses in the eighth ditch of Malebolge. Although the sin punished in that bolgia is never explicitly named in the poem, its victims are usually termed "counsellors of fraud" because we are told that one of them, Guido da Montefeltro, was brought there "perché diede 'l consiglio frodolente" (Inf. XXVII.116). ${ }^{1}$ The reader is left to formulate a definition of that sin from specific examples. In the case of Ulysses, Virgil gives us three crimes for which Ulysses suffers: the stratagem of the Trojan horse, whereby Troy was taken; the trick that revealed Achilles' identity when he had disguised himself as a woman to avoid going to his death in the Trojan war; and the theft of the Palladium, the talisman that had been keeping Troy safe from the Greeks. According to Virgil, all three schemes were complots in which Ulysses was associated with Diomedes, and for this reason the Pilgrim finds the two men tortured together within a single flame that has two tongues. Since in the next canto we find that Guido da Montefeltro suffers a similar punishment simply for devising a strategem without executing it himself, it appears that the sin of the place consists in using human reason to contrive tricks that gain an end through subterfuge.

Everyone agrees that Ulysses' tricks in the Trojan war earned him a place among the counsellors of fraud. The problem is whether his tragic flaw is exemplified in the long and eloquent 
description of his last voyage (Inf. XXVI.90-142) with which he answers Virgil's request to know where he went to die an unknown death. Ulysses' famous eloquence is easily discerned throughout this 53-line speech, but nowhere is his craftiness apparent. The hero explains to Dante and Virgil that, rather than return home to Ithaca in his old age, he was driven by curiosity to sail beyond the westward limit marked by the Pillars of Hercules and to explore the unknown Atlantic Ocean. He persuaded his men to undertake the perillous voyage by praising the quest as the proper exercise of man's specifically human powers: "you were not made to live as brutes," he told them, "but to pursue virtue and knowledge" (Inf. XXVI.119-20). After five months of sailing to the southwest, they discovered the mountain of the Terrestrial Paradise, but before they could land, a whirlwind issued from the mountain, creating a whirlpool that swallowed up ship and sailors.

It is on the interpretation of this passage that critical opinion is divided. ${ }^{2}$ Some claim that the voyage was an act of folly, and hence a perverted use of the human intellect. For them, Ulysses typifies man's intellectual pride: he rebelled against the limits of human knowledge set by God, and therefore he is a new Lucifer and a new Adam, and appropriately the Terrestrial Paradise was his downfall, as it was Adam's and Lucifer's. The objection to this view is that no obvious element of trickery is apparent in Ulysses' speech. He plainly says that he was curious and that he aroused the same curiosity in his men. Hence the voyage does not seem to exemplify the $\sin$ of fraudulent counsel, and Bruno Nardi, the leading proponent of the view that the voyage was an act of intellectual rebellion, could only reply lamely that this is a different, lesser sin than the one for which Ulysses is being punished. ${ }^{3}$ In that case, most critics agree, it is better not to consider the voyage as sinful at all, and indeed they can see nothing worthy of condemnation in Ulysses' voyage. Quite to the contrary, they find it altogether admirable. The hero, they claim, is none other than Aristotle's magnanimous man. Not only are the motives and actions of Dante's Ulysses admirable in themselves, but they suggest that he is the embodiment of the Greek intellect, the prototype of the Renaissance man, and the precursor of Western Europe's Faustian spirit. Thus we are left with the paradoxical problem that I set out to describe. In the prevailing opinion, the outstanding feature of the Ulysses episode appears to be irrelevant to his sin and leaves the reader with a favorable impression of the sinner. To be sure, not all modern critics are comfortable with this result, but we must be content with it unless it can be shown that the voyage involved Ulysses in one or more cunning frauds. 
I believe that Dante the poet was firm and, for the most part, successful in his resolve to imitate nature, and that like her, he did nothing in vain. The answers to the puzzles that he poses are always present in the Comedy if only one can find them. In this case, I think that the answer lies in the adjacent canto that is devoted to Guido da Montefeltro. The missing link is supplied by parallels between the case of Guido and that of Ulysses, so that one illuminates the other. Simply stated, Dante represents each man as guilty of a pair of tricks: one trick is a crafty military stratagem that ended a siege, while the other is an attempt to gain salvation by a ruse. Since both tricks are more evident in Guido's case, I shall examine that first and then return to Ulysses and show how he was guilty of the same pair of tricks.

Unlike Ulysses, Guido appears in the poem as an obvious trickster. He speaks freely about himself because he craftily supposes that the Pilgrim cannot emerge from Hell to bear back the truth to Italy (Inf. XXVII.61-66). He admits that all his life "my deeds were not those of the lion, but of the fox. I knew all wiles and covert ways, and plied the art of them so well that to the ends of the earth their sound went forth."

. . l'opere mie

non furon leonine, ma di volpe.

$\mathrm{Li}$ accorgimenti e le coperte vie

io seppi tutte, e sì menai lor arte,

ch'al fine de la terra il suono uscie. (Inf. XXVII.74-78)

But, unlike Ulysses, Guido is not in Hell because of the frauds he devised while a soldier; instead, he attributes his perdition entirely to an episode in his declining years, which he recounts in detail. He himself explains the difference between the two cases:

Quando mi vidi giunto in quella parte

di mia etade ove ciascun dovrebbe

calar le vele e raccoglier le sarte,

ciò che pria mi piacëa, allor $m$ 'increbbe,

e pentuto e confesso mi rendei;

ahi miser lasso! e giovato sarebbe. (Inf. XXVII.79-84)

When I saw myself come to that part of my life when every man should lower the sails and coil up the ropes, that which before had pleased me grieved me then, and with repentance and confession I turned friar, and - woe is me! - it would have availed.

As a Christian, Guido could put his sins behind him and die repentant. His tragedy is that he did not. 
The focus, then, is on the right use of old age. We can be sure that this was what Dante intended, because in the Convivio he cited the example of Guido's retirement with approval. He is explaining that in the fourth and final age of human life, which he calls "senio" that is "senility" or "decline" - the noble soul "returns to God as to that haven whence she set forth when she came to enter on the sea of this life." metaphor of life's voyage, and I shall quote it at length, not only because Guido uses the same metaphor in the poem, but also because it contains a striking parallel to Ulysses' last voyage.

And here we must know, as Tully says in his book On Old Age [De Senectute 19.70], "a natural death is, as it were, a haven for us and resting-place after a long voyage." And so just as a good mariner when he draws near to the harbour lets down his sails, and enters it gently with slight headway on; so we ought to let down the sails of our worldly pursuits, and turn to God with all our understanding and heart, so that we may come to that haven with all composure and with all peace.

The noble soul ... seems to herself ...to be leaving the ocean and returning to port. $\mathrm{O}$ vile wretches who run into this port with sails full set, and in the harbour where ye ought to repose, wreck and destroy yourselves by the force of the wind at the spot to which ye have so long been journeying! Truly the knight Lancelot, and our noblest of Latins, Guido of Montefeltro, did not wish to enter port with sails full set. These noble men indeed shortened the sail of their worldly occupations, for in their extreme age they surrendered themselves to religion, laying aside all worldly delights and pursuit. ${ }^{5}$

For the moment, let us consider only what this passage tells us about the case of Guido. Dante, when he wrote the Convivio, had no doubt that Guido was "the noblest of Latins" ("lo nobilissimo nostro latino"). Furthermore, Dante considered Guido's retirement from military life into the Franciscan order to be exemplary. Thus, unless it can be shown that the poet had changed his mind about old age by the time that he wrote the Inferno, it cannot be denied that he thought that the proper activity of one's declining years was retirement. The fact that the metaphor of the Convivio is echoed in the Inferno suggests that the poet not only still maintained that position but also that he wished to draw the reader's attention to his earlier discussion. The echo, then, serves to confirm the impression conveyed by Guido's speech, namely that the stress in his case lies on the right use of old age. Hence, to determine his sin, we must focus on whether he used his retirement rightly. 
All that we know of Guido's years as a Franciscan is what he tells us. ${ }^{6}$ According to Dante, Guido devised the strategem that enabled Pope Boniface VIII to capture the city of Palestrina, in which the pope was besieging his enemies, the Colonna family. Obviously, this is a trick that parallels Ulysses' devices that brought about the fall of Troy, and as such it should in itself account sufficiently for Guido's damnation. Yet, strange to say, it is not the crux of the episode that Guido relates. He is damned for devising a fraud, to be sure, but also for failing to repent it, as he apparently had repented his earlier tricks. Indeed, there is no indication that Guido in Hell does regret giving the counsel itself; instead, his remorse is directed at his failure to comply with the formal requirements of the sacrament of penance. To overcome Guido's reluctance to return to his former ways, the pope absolved his counsellor in advance of any sin he might commit in giving counsel. Boniface argued that this was within his power because, as pope, he held the keys to Heaven. Guido, convinced by this argument that he could sin with impunity, gave the required counsel (Inf. XXVII.100-11), only to discover after his death that he had been proceeding under a misapprehension. As the black cherubim who took him to Hell explained, one cannot repent in advance, and one cannot be absolved unless one repents (Inf. XXVII.112-20); hence in his case there was neither true repentance nor true absolution.

The scene in which the fallen angel and Saint Francis dispute over Guido's soul may seem naive in its medieval simplicity, but it does serve a useful purpose. From it the reader is given to understand that it is indubitably God's judgment that Guido was personally responsible for his failure to repent properly. He was, we are assured, not acting in good faith. Or, put another way, he was trying to trick God. Guido knew that Boniface was asking him to commit a sin, and when the pope offered him a way to do it without endangering his salvation, the old fox readily accepted. Accordingly, it was Guido's life-long habit of trickery that brought about his downfall. Instead of using his old age to repent his frauds, he practiced them up to the end; indeed, he did not hesitate to practice them on God Himself.

This conclusion is confirmed by the simile of Perillus, which the poet uses earlier in the canto to describe how Guido's words emerge from the flame that envelops him. Perillus had invented an instrument of torture consisting of a brass bull inside which a victim could be roasted alive while outside his anguished cries sounded like the bellowing of the bull (Inf. XXVII.7-12). 'Appropriately, the first to perish in this device was Perillus, who had invented it. Thus Perillus is the image of the cunning man who is 
caught in his own trap. The poet explicitly compares Guido's voice in his flame to that of Perillus in his bull, but a further comparison is implied, since both were victims of their own misguided ingenuity.

Hence it seems clear that Guido at the end of his life was guilty of two tricks, not one: the first was the siege stratagem that he devised for Boniface; the second was his attempt to gain salvation by a ruse. Finally, it should be noted that he retains his disposition to trickery even in Hell. As has been remarked above, he expresses no remorse for the fraud that he devised for Boniface, but only for its unexpected consequences; moreover, he is crafty in his dealings with the Pilgrim, whom he obliges only because he supposes that his tale will not get back to Italy. Ironically, here again he is the victim of his own cunning.

The case of Guido invites comparison with that of Ulysses. Not only are they found in the same place in Hell, but we are told that one flame "came on behind" the other ("che dietro a lei venia": Inf. XXVII.4), and moreover, a whole canto is devoted to each case. With such symmetry, one may expect further parallels, and they are not far to seek. Both men seem to owe their place in Hell to a trick that ended a siege - that of Troy in one case and of Palestrina in the other. Another parallel is less obvious, though none the less striking once it is pointed out: in each case, life is represented as a voyage that ends in disaster. Guido's voyage is metaphorical, whereas Ulysses' is a real one. Either one might fit the description Dante gave in the passage from the Convivio that was quoted above: "O vile wretches who run into this port [of death] with sails full set, and in the harbour where ye ought to repose, wreck and destroy yourselves by the force of the wind at the spot to which ye have so long been journeying!" (Conv. IV.xxviii.7). Indeed, Ulysses' end fits so well that one naturally wonders whether this metaphor in the Convivio did not suggest to the poet the death by whirlwind that he invented for Ulysses. Certainly this seems plausible, since the last adventure of Ulysses exemplifies what Dante thought was the wrong way to round out one's life. The poet has the hero act out the metaphor of life's voyage by having him sail to his death rather than retiring in old age. What is more, one cannot object that Ulysses was being judged by standards alien to his culture, for it was from a pagan author, namely from Cicero, that Dante borrowed the image of gliding into death's harbor.

The text of the poem itself indicates clearly that the voyage was wrong. Ulysses acknowledges that the destruction of his ship was the will of God, for he says that it sank "as pleased Another" ("com' altrui piacque": Inf. XXVI.141). Only later in the poem does the 
reader learn why it was wrong for a living man to attempt to sail to the Terrestrial Paradise. Adam and Eve left the mountain after the Fall (Par. XXVI.139-42), and since the Redemption human souls are returned thence by an angelic ferryman (Purg. II.16-51, 94-105). When Ulysses made his voyage, between the Fall and the Redemption of mankind, therefore, the sacred mount was forbidden to Adam's descendants; and even after the Redemption, only dead souls bound for Heaven normally had legitimate access to the mount, and that solely through the intermediary of the angelic ferryman.

To be sure, Ulysses could not have known how his voyage violated the divine plan, but he did know that the waters he was sailing into were forbidden to men. This fatal knowledge is indicated by his own words to the Pilgrim: "we came to that narrow outlet where Hercules set up his markers, that men should not pass beyond."

\section{...venimmo a quella foce stretta}

dov' Ercule segnò li suoi riguardi

acciò che l'uom più oltre non si metta. (Inf. XXVI.107-9)

Dante here refers to a widespread legend, going back ultimately to Pindar, to the effect that the Pillars of Hercules were erected as a sign warning travellers to go no further. ${ }^{8}$ Since Hercules, who set up the pillars, was an ancient exemplar of the wise man, ${ }^{9}$ it would have been folly to ignore his prohibition, and indeed Dante explicitly labels the act as such when he says that, while looking down from the Firmament, "beyond Cadiz, I saw the mad track il varco folle of Ulysses" (Par. XXVII.82-83). Furthermore, it is possible, as Giorgio Padoan suggested, that Dante regarded Hercules' prohibition as having been divinely inspired..$^{10}$ At any rate, it is clear from the poem that as Ulysses approached the Pillars of Hercules, he thought it necessary to overcome his crew's hesitancy to transgress the limit set by Hercules (Inf. XXVI.112-20). What is not clear is whether the "little speech" with which he accordingly exhorted his men was delivered in good faith. ${ }^{11}$ The parallel case of Guido da Montefeltro can, I believe, resolve this question. We have seen that Ulysses' last voyage is linked to the final episode of Guido's life by a common image; we have also seen that Ulysses, like Guido, knew that his last venture was contrary to wisdom; and now we must ask whether the parallel is complete. The crucial question is this: Is it possible that Ulysses' last voyage can be viewed as an attempt to gain salvation by a ruse?

Indeed it can, for pagan antiquity believed that somewhere 


\section{4}

beyond the Pillars of Hercules lay the Isles of the Blessed, where departed heroes lived forever on the Elysian Fields in a land without winter. For a living man to sail to these Fortunate Isles would be, in effect, to secure immortal happiness, the greatest gift of the gods, without divine intervention. Thus human ingenuity could circumvent the judgment of the gods and gain salvation by a ruse. At the least we can say that this could plausibly have been Ulysses' tacit goal.

Though plausible, this view of Ulysses' destination will hardly be acceptable without further justification. To be sure, it is the answer that readily suggests itself to the modern reader who has been led by the parallels between Guido and Ulysses to ask whether the end of the one resembled that of the other. But it remains to be seen whether the same solution would have occurred to Dante.

At first glance, it would seem that Dante himself had a quite different conception of the Fortunate Isles. He mentions them only once, when he quotes Orosius' statement that the western end of Africa is bounded by Mount Atlas and the Fortunate Isles. ${ }^{12}$ Thus it would appear that they were a geographic reality to Dante, to be identified with the Canaries. ${ }^{13}$ Moreover, he does not locate Elysium on these islands but rather in the underworld, ${ }^{14}$ albeit somewhat guardedly, for it is explicitly on Virgil's authority that he does so:

Sì pia l'ombra d'Anchise si porse,

se fede merta nostra maggior musa,

quando in Eliso del figlio s'accorse. (Par. XV.25-27)

Thus it would seem that Dante himself did not make explicit use of the classical concept of the Blessed Isles, and indeed, on this evidence, one might well doubt that he was even aware of it.

This doubt grows when one traces the development of the myth of the Blessed Isles. ${ }^{15}$ Already in the Odyssey (4.563-68) the Elysian Fields appear as the happy home of a few favored mortals, which Homer placed on the westernmost shore of the world; but it was Hesiod who first located these fields on an Isle of the Blessed (Opera et Dies 169-73), somewhere in the Atlantic Ocean itself. As a religious concept, this myth was already becoming outmoded in the fifth century B.C., when it found its finest literary expression in Pindar (Olympia 2.77-91) and Euripides (Bacchae 1339 and (Helena 1676-77). As Greek religion and philosophy developed a less materialistic view of the afterlife, however, the myth lost much of its appeal. By the time of Augustus, the exploration of both the 
Canaries and Madeira had manifestly discredited the assertions of the early Greek poets. ${ }^{16}$ A few writers under the Empire still attempted to maintain the credibility of an earthly paradise by moving its location farther out into the Atlantic, ${ }^{17}$ but the most common solution was Virgil's, namely to place Elysium in the underworld, beyond the attention of the geographers.

Certainly Dante had no direct knowledge of the Greek poets who placed Elysium on some island in the West. Instead, his poetic sources were Latins who wrote when the myth was only a faded relic from the past. Therefore, we cannot assume that Dante knew the early, Greek concept of the Blessed Isles; but, on the other hand, we cannot exclude the possibility that he did know it from some later, Latin source or sources. For our purpose it does not matter if these later sources no longer believed the myth. The important question is whether Dante could have known that it was current in Ulysses' time. To answer this question, we have but to consult Dante's favorite authors, and especially those who are presented as authorities in the Commedia itself.

As one might expect, the encyclopedic Isidore of Seville included the Fortunate Isles among the islands described in his Etymologiae: ${ }^{18}$

The Fortunate Isles signify by their name that which bears all good things, as if they were called lucky or blessed because of the abundance of fruits. For being apt by their nature, they are full of the fruits of precious plants; chains of hills are clothed by chance vines; instead of a crop of ordinary grass, generally it is a pot-herb. Whence pagan error and the songs of the secular poets held these islands to be Paradise because of the fruitfulness of the soil. They are, however, located in the Ocean opposite to the left side of Mauretania, are nearest to the setting sun, and are separated from one another by a sea that lies between them.

I am considering Isidore first because he presented the Fortunate Isles from a Christian viewpoint, which most likely approximates Dante's own, since he placed Isidore among the learned souls who accompany Aquinas in the Heaven of the Sun (Par. X.131). From Isidore we learn that the Fortunate Isles exist both in fact and in fiction. Because Isidore wished to discredit the fables of paganism, he stressed the facts at the expense of the fiction: the favored climate of the Canaries made them seem to be Paradise to pagans whose materialism knew no higher conception of the afterlife. But even Isidore does not impute such materialism to all pagans, for some are not in error but are merely poets who are secular, i.e. not writing in the Christian tradition. For them it was a matter of convention to locate Paradise in the Fortunate Isles; they did not 
necessarily present this as a fact but quite possibly as a fiction. Thus from Isidore Dante could learn that some poets of antiquity sang of a fictional island paradise in the Atlantic, which other pagans took literally to be the actual abode of fortunate souls in the afterlife. It remains to be seen whether Dante might reasonably have imagined Ulysses to have been one of those pagans. ${ }^{19}$

Accordingly, the important point to establish now is that Dante knew that the concept of the Blessed Isles flourished among the early Greeks. This he could have discovered from a variety of sources, but I shall insist on only two, Cicero and Aristotle, both of whom were among his favorite authors. Cicero mentions the Blessed Isles in a work with which Dante was especially familiar, the De Finibus Bonorum et Malorum: "The old philosophers picture what the life of the Wise will be in the Islands of the Blest, and think that being released from all anxiety and needing none of the necessary equipment or accessories of life, they will do nothing but spend their whole time upon study and research in the science of nature." ${ }^{20}$ These old philosophers sound less frivolous than the poets whom Isidore mentions, but Cicero is careful to indicate by the verb "fingunt" that what they said of the Blessed Isles was a fabrication, a product of imagination - in short, a myth. Elsewhere, Cicero put it more bluntly, when he simply relegated the Blessed Isles to the realm of myth with the reference "ut fabulae ferunt." 21

Dante knew one of these old philosophers well and doubtless read for himself what Aristotle said about the Blessed Isles in the Politics: "Those then who seem to be the best-off and to be in the possession of every good, have special need of justice and temperance, - for example, those (if such there be, as the poets say) who dwell in the Islands of the Blest; they above all will need philosophy and temperance and justice, and all the more the more leisure they have, living in the midst of abundance. ${ }^{22}$ Moreover, since Dante seems to have read his Aristotle in conjunction with Aquinas' commentary, he probably also knew this explanation: "According to the poets, there are certain islands in which the souls of those who act well while they are living continue in happiness after death. ${ }^{\prime 23}$ Finally, it is even possible that Dante might have known Homer's line about the Elysian Plains that is preserved in the Aristotelian Problemata. ${ }^{24}$

The essential point is that Aristotle, both in the Politics and in the Problems, makes it clear that what he says about the Blessed Islands has been derived from earlier Greek poets. Furthermore, in the passage from the Politics, Aristotle indicates that his example is to be taken, not literally, but hypothetically, as a fiction borrowed 
from the poets: the fortunate in reality are "just as if" ("velut $\mathrm{si}^{\text {") }}$ they were the fortunate in poetic fiction. Thus we can conclude that Dante was in a position to know that the Blessed Isles belonged to the fictions of the early Greek poets. Hence, when inventing his own fiction of Ulysses' last voyage, Dante most probably knew that it was both plausible and appropriate to have his hero, an early Greek, set off in search of the kind of bliss that was celebrated by the early Greek poets.

This general line of argument can be reinforced by two other indications that Dante's treatment of the Ulysses episode was influenced by classical references to the Fortunate Isles. One comes from Servius, whose commentary on the Aeneid Dante seems to have used for other details of the Commedia. ${ }^{25}$ At Aeneid 6.532, Servius notes that the Fortunate Isles are located in the Antipodes. ${ }^{26}$ Although Dante had other reasons for locating his Terrestrial Paradise in the southern hemisphere, where Eden could stand opposite to Jerusalem, still Servius may have suggested that it could be equated with the Fortunate Isles of classical antiquity. Without the location provided by Servius, it is hard to explain why Ulysses sailed not only west but also south; his southerly course makes sense, however, if we understand that the Fortunate Isles lay not only to the west of Europe, as was commonly believed, but also to the south, as Servius attests. Once again, therefore, the evidence suggests that Ulysses' goal was the Earthly Paradise as he knew it.

Our final witness is the poet Horace, one of the five classical poets especially honored in the Noble Castle (Inf. IV.89), whose Epodes seemingly were known to Dante. ${ }^{27}$ Epode 16 celebrates the Fortunate Isles in terms that may well have suggested to Dante his version of Ulysses' last voyage. The poet deplores the civil strife of the past two generations, and he offers an alternative to his warweary world: let all worthy Romans set sail to settle in the Fortunate Isles! "Us the encompassing Ocean awaits. Let us seek the Fields, the Happy Fields, and the Islands of the Blest. . . ."

nos manet Oceanus circumvagus; arva, beata petamus arva divites et insulas,

(Epodon 16.41-42)

After praising the temperate climate and the abundant crops and herds, he asserts that the land had not been explored by the famous seafarers of the past because it has been reserved for a righteous race, such as his own: "Hither came no ship of pine with straining Argo's oarsmen, nor here did any shameless Colchian queen set 
foot; no Sidonian mariners hither turned their spars, nor Ulysses' toiling crew. . . Jupiter set apart these shores for a righteous folk, ever since with bronze he dimmed the lustre of the Golden Age."

non huc Argoo contendit remige pinus, neque impudica Colchis intulit pedem; non huc Sidonii torserunt cornua nautae, laboriosa nec cohors Ulixei.

Iuppiter illa piae secrevit litora genti, ut inquinavit aere tempus aureum. (Epodon 16.57-60, 63-64) ) $^{2 n}$

To be sure, Horace claims that Ulysses did not attempt the voyage to the Fortunate Isles; nevertheless, by that very assertion he raises the possibility that the hero might have attempted such an adventure. If any literary source suggested to Dante his version of Ulysses' last voyage, the most likely to have done so is this passage from Horace, to which Dante's Ulysses episode stands as an alternative myth. This seems all the more likely because Horace supplies the reason for Ulysses' failure in Dante's version, namely that the Earthly Paradise had been reserved by God for the righteous. Admittedly any argument for influence of this sort must be tenuous, but still it is strengthened by the other connections that we have already established between Ulysses' last voyage and the myth of the Fortunate Isles. At least we can be certain that there is now good reason to assume that the tacit goal of Dante's Ulysses was the Fortunate Isles, and with that assurance we can conclude this excursus and return to the main line of our investigation.

From a study of Dante's possible sources, we know that he could have made the Fortunate Isles Ulysses' secret destination. But can we be sure that such was Dante's intention? One indication, of course, is the structured series of parallels that has led us progressively to our conclusion. Another is the southerly bearing of Ulysses' course, which can best be accounted for by assuming that he was seeking the Fortunate Isles in the Antipodes, where Servius had indicated they were to be found. But, as is often the case, the poet has also given his reader a countersign, which is to say another clue that serves to reassure those who follow the poet's meaning successfully that they have been on the right track. In Guido's canto the Perillus simile served such a purpose; here, in Ulysses' canto, it is the simile of Elijah, who ascended into Heaven in a flame as impenetrable to human vision as the flames that envelop the counsellors of fraud (Inf. XXVII.34-39). The biblical 
basis for this simile is a single verse in 4 Kings 2.11: "And as they [Elias, i.e. Elijah, and his disciple, Elisha] went on, walking and talking together, behold a fiery chariot, and fiery horses parted them both asunder: and Elias went up by a whirlwind [per turbinem] into heaven. ${ }^{\prime 29}$ The whirlwind is the common feature that links the ascent of Elijah to the descent of Ulysses, as is apparent from the poem. When Ulysses and his men saw the Terrestrial Paradise, "we rejoiced," he says, "but soon our joy was turned to grief, for from the new land a whirlwind [un turbo] rose and struck the forepart of the ship. Three times it whirled her round with all the waters, and the fourth time it lifted the stern aloft and plunged the prow below, as pleased Another, till the sea closed over us."

Noi ci allegrammo, e tosto tornò in pianto;

ché de la nova terra un turbo nacque

e percosse del legno il primo canto.

Tre volte il fé girar con tutte l'acque;

a la quarta levar la poppa in suso

e la prora ire in giù, com' altrui piacque,

infin che 'l mar fu sovra noi richiuso. (Inf. XXVI.136-42)

Once the two passages are juxtaposed, less obvious similarities become apparent. In both cases, the whirlwind is sent by God, as a reward to Elijah and as a punishment to Ulysses. Since the results are diametrically opposed, we may wonder why divine justice found it appropriate to use the same instrument in both cases. The answer, of course, is that the cases are correlative. The case of Elijah shows us that a living man can pass directly to his eternal reward when the initiative comes from God. Ulysses presents the contrasting case of a man who seeks to attain immortal happiness on his own initiative, and indeed, in a way that is expressly prohibited to him. Thus the Elijah simile confirms what we have already discovered about Ulysses' last voyage: like the final episode of Guido's life, it was an attempt to trick God. From this it follows that Ulysses concealed his true purpose, both from his men and from the Pilgrim, and hence it now appears that in his "small speech" Ulysses was manipulating his crew.

These discoveries raise a final problem: What is the sin that is being punished in the eighth bolgia? The black cherubim announced that Guido was damned "because he gave the fraudulent counsel" (Inf. XXVII.116). But is Ulysses' exhortation to his men a fraudulent counsel? If so, we must understand "consiglio frodolente" to include not only cases in which the adviser suggests a fraud to the advisee, but also cases in which the advisee himself is 
fooled by the adviser. Moreover, we have noted that both Guido and Ulysses attempted to outwit God Himself, and we may well wonder whether this, too, is an instance of the sin of the eighth bolgia, even though it was committed without the giving of counsel. Obviously, a broader definition of the sin is in order, and Dante does not leave us at a loss to discover it. The clue lies in the fact that he felt that the sin was especially inappropriate during the fourth and final age of human life, namely senio. This suggests that Dante may have considered it to be in some way more appropriate at an earlier age. And such does indeed prove to be the case when we turn back in the Convivio to Dante's discussion of the third age of man, which he calls "old age" ("senettude"). There we find the sin of both Guido and Ulysses aptly described and explicitly named.

It is meet, therefore, that a man should be prudent, that is, wise; and for becoming wise there are required good memory of things that have been seen, good apprehension of things present, and good foresight of things future. And as the Philosopher says in the sixth book of the Ethics, "it is impossible for a man to be wise unless he is good"; and therefore a man who proceeds with subterfuge and deceit is not to be called wise but astute [astuto]; for just as no one would call a man wise who knew how to hit the pupil of an eye with a dagger, so a man is not to be called wise who knows well how to commit a bad action, by doing which he always wrongs himself before he wrongs another ${ }^{30}$

Thus it appears that the sin of Ulysses and Guido is properly to be called astutia, that is "astuteness," or better, "cunning." Though never licit, it is all the more inappropriate in the final age of man, when the truly wise man retires to contemplate the past and future. Because neither Guido nor Ulysses could cease to exercise their ingenuity, we learn that cleverness was for them a vice, a bad habit to which they were overly attached and by which they were in consequence flawed fatally. Their tragedy is that they had been born with the capacity for wisdom, but because they did not use it for good purposes, they were merely cunning. I think that there can be no doubt that such was the poet's view, because he clearly enunciates that principle as he prepares us for his description of the eighth bolgia:

Allor mi dolsi, e ora mi ridoglio quando drizzo la mente a ciò ch'io vidi, e più lo 'ngegno affreno ch'i' non soglio, perché non corra che virtù nol guidi;

sì che, se stella bona o miglior cosa m'ha dato'l ben, ch'io stessi nol m'invidi. 
I sorrowed then, and sorrow now again, when I turn my mind to what I saw; and I curb my genius more than I am wont, lest it run where virtue does not guide it; so that, if a kindly star or something better has granted me the good, I may not deprive myself of it..$^{31}$

Thus it appears beyond question that the sin of the eighth bolgia is astutia. Clearly this includes all of the various tricks that are found in cantos XXVI and XXVII of the Inferno: not only the siege stratagems, but also the illicit attempts to gain salvation by a ruse, and even Ulysses' manipulative speech to his crew. Hence the twin cantos now can be seen as a tightly integrated structure, in which the poet has exemplified the sin of the place with great economy. Specifically, Ulysses' voyage, which has long seemed irrelevant to the sin of fraudulent counsel, now can be recognized as an audacious act of cunning. Those who admire the noble sentiments with which Ulysses manipulated his crew may well feel cheated: the great Greek has deceived them as well.

\section{University of Kansas}

\section{NOTES}

*A shorter version of this paper was read at the 14th International Congress on Medieval Studies, Kalamazoo, Michigan, 6 May 1979.

1 Throughout this paper, the text and translation of the Commedia is that of Charles S. Singleton, The Divine Comedy Translated, with a Commentary, Bollingen Series, No. 80 (Princeton, 1970-75). On the sin, see E. Bonora, "Consiglieri di frode," Enciclopedia dantesca, 5 vols. (Roma, 1970-76), II, 158-59.

2 I greatly simplify a complex debate, which is more fully summarized by $M$. Fubini, "Ulisse," Enciclopedia dantesca, V, 803-9.

3 Bruno Nardi, "La tragedia d'Ulisse," in his Dante e la cultura medievale, 2nd ed. (Bari, 1949), pp. 153-65, at p. 165.

4 Conv. IV.xxviii.2, trans. William W. Jackson, Dante's Convivio (Oxford, 1909), p. 291; ed. Maria Simonelli, Il Convivio, Testi e saggi di letterature moderne: Testi, No. 2 (Bologna, 1966), p. 215: "ella ritorna a Dio, sì come a quello porto, onde ella si partio quando venne ad intrare nel mare di questa vita."

5 Conv. IV.xxviii.3, 7-8, trans. Jackson, pp. 291-93; ed. Simonelli, pp. 215-16: "E qui è da sapere che, sì come dice Tullio in quello De Senectute, la naturale morte è quasi a noi porto di lunga navigazione e riposo. Ed è così: come lo buono marinaio, come esso appropinqua al porto, cala le sue vele, e soavemente, con debile conducimento, entra in quello; così noi dovemo calare le vele de le nostre mondane operazioni e tornare a Dio con tutto nostro intendimento e cuore, si che a quello porto si vegna con tutta soavitade e con tutta pace. . . . La nobile anima ... uscir le pare di mare e tornare a porto. O miseri e vili che con le vele alte correte a questo porto, e là ove dovereste riposare, per lo impeto del vento rompete, e perdete voi medesimi là dove tanto camminato avete! Certo lo cavaliere Lancelotto non volse entrare con le vele alte, né lo nobilissimo nostro latino Guido montefeltrano. Bene questi nobili calaro le vele de le mondane operazioni, che ne la loro lunga etade a religione si rendero, ogni mondano diletto e opera disponendo."

6 The historical truth of the story is doubtful: see A.B. Langeli, "Palestrina," Enciclopedia dantesca, IV, 260-61. 
7 Singleton, Inferno: Commentary, pp. 472-73.

8 The Pillars were often taken to be simple landmarks signalling the extreme western limit of the earth, e.g. by Brunetto Latini, Tresor 1.123.23 and Tesoretto 1043-52, both quoted by Singleton, Inferno: Commentary, pp. 465-66. But, as Singleton notes, Dante's "più oltre non" goes further by echoing the prohibition of the familiar Latin "ne plus ultra." What was his source? Curiously, the motto ne (or nec or non) plus ultra does not appear among the medieval Latin proverbs collected by Hans Walther, Proverbia Sententiaeque Latinitat is Medii Aevi: Lateinische Sprichwörter und Sentenzen des Mittelalters in alphabetischer Anordnung, Carmina Medii Aevi Posterioris Latina, No. 2, 5 vols. (Göttingen, 1963-67). The idea is expressed in much the same words, however, by a scholium to Juvenal, Saturae 5.14.280, ed. Otto Jahn et al., A. Persii Flacci, D. Iunii Iuvenalis, Sulpiciae Saturae (Berlin, 1910), p. 260: "ultra Herculis columnas dicit ad mare mortuum, ultra quod navigare non conceditur." Dante might have known this source, since it now appears that he did know Juvenal's poems directly: E. Paratore, "Giovenale," Enciclopedia dantesca, III, 197-202. On the Pillars and their prohibition in antiquity, see A. Schulten, "Die 'Säulen des Herakles," in Otto Jessen, Die Strasse von Gibraltar (Berlin, 1927), pp. 174-206, esp. pp. 181 (Pindar), 198-99 (Schol. Juvenal).

9 Seneca, De Constantia Sapientis 2.1, linking Ulysses with Hercules as traditional types of the wise man.

10 G. Padoan, "Ercole," Enciclopedia dantesca, II, 717-18, at p. 718; also his article, "Il mito di Teseo e il cristianesimo di Stazio," Lettere italiane, 11 (1959), 432-57, at p. 441. Marcel Simon argued that Dante used Hercules as a figure for Christ: Hercule et le christianisme, Publications de la Faculté des lettres de l'Université de Strasbourg (Paris, [1955]), pp. 177-79.

11 Generally the "orazion picciola" is taken at face value, but the contrary opinion of Lane Cooper is reported by Fubini, Enciclopedia dantesca, V, 805.

12 Monarchia II.iii.13, ed. Pier Giorgio Ricci, Le opere di Dante Alighieri; Edizione nazionale a cura della Società dantesca italiana, No. 5 (Milano, 1965), p. 179: "dicit Orosius Historia Adversos Paganos 1.2 in sua mundi descriptione sic: 'Ultimus autem finis eius est mons Athlas et insule quas Fortunatas vocant'; 'eius,' idest Affrice, quia de ipsa loquebatur."

13 So identified, e.g., by A. Cecilia, "Fortunate, Isole," Enciclopedia dantesca, II, 986.

14 C. Kraus, "Eliso," Enciclopedia dantesca, II, 659.

15 C.T. Fischer, "Fortunatae insulae," Paulys Real Encyclopadie der classischen Altertumswissenschaft, ed. Georg Wissowa and Wilhelm Kroll (Stuttgart, 1912), VII, 42-43; F.W. Hall, "Blest, Abode of the (Greek and Roman)," Encyclopaedia of Religion and Ethics, ed. James Hastings (1909; rpt. New York, 1951), II, 696-98; Herbert Jennings Rose, A Handbook of Greek Mythology, Including Its Extension to Rome, (London: Methuen, 1953'), p. 80; H. Treidler, "Fortunatae Insulae," Der kleine Pauly; Lexikon der Antike, ed. Konrat Zeigler and Walter Sontheimer (Stuttgart, 1967), II, 600.

16 M. Cary and E.H. Warmington, The Ancient Explorers, 2nd ed. (Baltimore, 1963), pp. 69-71.

17 Ibid., p. 242 (e.g. Plutarch).

18 Isidore, Etymologiae 14.5.8, ed. W.H. Lindsay, Isidori Hispalensis Episcopi Etymologiarum sive Origenes Libri XX (1911; rpt. Oxford, 1966): "Fortunatarum insulae vocabulo suo significant omnia ferre bona, quasi felices et beatae fructuum ubertate. Sua enim aptae natura pretiosarum poma silvarum parturiunt; fortuitis vitibus iuga collium vestiuntur; ad herbarum vicem messis et holus vulgo est. Vnde gentilium error et saecularium carmina poetarum propter soli fecunditatem easdem esse Paradisum putaverunt. Sitae sunt autem in Oceano contra laevam Mauretaniae, occiduo proximae, et inter se interiecto mari discretae."

19 Dante's own Terrestrial Paradise is, of course, itself a poetic fiction, which may be regarded as the Christian development of the western island Paradise that, according to Isidore, was the subject of "saecularium carmina poetarum." 
20 Cicero, De Finibus Bonorum et Malorum 5.19.53, trans. H. Rackham, 2nd ed., Loeb Classical Library (London, 1931), pp. 453-54: "Ac veteres quidem philosophi in beatorum insulis fingunt qualis futura sit sapientium, quos cura omni liberatos, nullum necessarium vitae cultum aut paratum requirentes, nihil aliud acturos putant nisi ut omne tempus inquirendo ac discendo in naturae cognitione consumant." According to Edward Moore, Dante used this work 8 times, 5 of which are beyond question: Studies in Dante, First Series (1896; rpt. New York, 1968), pp. 353-54.

21 Cicero, Hortensius, quoted by Augustine, De Trinitate 14.9.12, ed. J.P. Migne, Patrologia Latina, 42:1046: "Tullius in Hortensio dialogo disputans: 'Si nobis' inquit 'cum ex hac vita emigravimus, in beatorum insulis immortale aevum, ut fabulae ferunt, degere liceret quid opus esset eloquentia, cum judicia nulla fierent; aut ipsis etiam virtutibus?" Dante's use of this source is not attested.

22 Aristotle, Politica 7.15, 1334a30, trans. Benjamin Jowett, in The Works of Aristotle, ed. W.D. Ross, X (Oxford, 1921); Latin version printed in S. Thomae Aquinatis In Octo Libros Politicorum Aristotelis Expositio, ed. Raymund M. Spiazzi (Torino, 1951; rpt. 1966), p. 390, Text No. 1061: "Multa igitur indigent iustitia et multa temperantia, qui optime videntur agere et omnibus beatis frui; velut si qui sunt, sicut poëtae aiunt, in beatorum insulis, maxime enim ii indigebunt philosophia, et temperantia, et iustitia, quanto magis vacant in abundantia talium bonorum." Dante's use of the Politics is firmly attested 14 times, and less certainly 8 more times, according to Moore, Dante Studies, First Series, pp. 342-43.

23 S. Thomae Aquinatis ... In Octo Libros Politicorum Aristotelis Expositio, ed. Spiazzi, p. 394, Comm. No. 1218: "sicut si qui sunt in insulis beatorum, sicut poëtae dicunt, dicentes insulas quasdam esse in quibus animae bene operantium dum vivunt feliciter perseverant post mortem." The passage occurs in Peter of Auvergne's continuation of Aquinas' unfinished commentary.

24 Pseudo Aristotle, Problemata 26.31, 943b21-23, trans. E.S. Forster in The Works of Aristotle, ed. W.D. Ross (Oxford, 1927): "Why is the West wind always considered to bring fair weather and to be the pleasantest of the winds? So, for instance, Homer says that in the Elysian Plains 'Ever the breezes blow of the Zephyr" ' (Odyssea 4.567). By 1303 the Problemata was known at Padua through the commentary by Pietro d'Abano: Friedrich Ueberwegs Grundriss der Geschichte der Philosophie, Pt. 2, ed. Bernhard Geyer, 12th ed. (Basel, 1951), p. 614.

25 A. Ronconi, "Echi virgiliani nell'opera dantesca," Enciclopedia dantesca, V, 104449, at pp. 1046-47.

26 Servius, Comm. in Aen. 6.532, ed. Georg Thilo and Hermann Hagen, Servii Grammatici Qui Feruntur in Vergilii Carmina Commentarii, II (Leipzig, 1884), 76: "Alii altius intellegunt: qui sub terra esse inferos volunt secundum chorographos et geometras, qui dicunt terram $\sigma \phi \alpha \iota \rho \circ \in \iota \delta \tilde{\eta}$ esse, quae aqua et aere sustentatur. Quod si est, ad antipodes potest navigatione perveniri, qui quantum ad nos spectat, inferi sunt, sicut nos illis." Cf. ibid., p. 27 ( $A \in \nu .6 .127$ ).

27 G. Brugnoli and R. Mercuri, "Orazio," Enciclopedia dantesca, IV, 173-80, at p. 176, are extremely cautious in attributing direct knowledge of Horace to Dante, but they admit there is a strong case for Epode 15.

28 Horace, The Odes and Epodes, trans. C.E. Bennett, Loeb Classical Library, 2nd ed. (London, 1927), pp. 411, 413.

294 Kings 2.11: "Cumque pergerent, et incedentes sermocinarentur, ecce currus igneus, et equi ignei diviserunt utrumque: et ascendit Elias per turbinem in caelum." Vulgate text as ed. Carlo Vercellone, Biblia Sacra Vulgatae Editionis (1861; rpt. Paris, 1891); Douay-Rheims trans., rev. R. Challoner, The Holy Bible Translated from the Latin Vulgate (New York, 1899). Singleton, Inferno: Commentary, p. 454, quotes the verse as the source of Inf. XXVI.34-39, but he does not note the parallel to the "turbo" of Inf. XXVI.137. Cf. Eccli. 48.13: "Elias quidem in turbine tectus est."

30 Conv. IV.xxvii.5, trans. Jackson, pp. 287-88; ed. Simonelli, p. 211: "Conviensi adunque essere prudente, cioè savio; $\mathrm{e}$ a ciò essere si richiede buona memoria de le vedute cose, buona conoscenza de le presenti e buona provedenza de le 
future. E, sì come dice lo Filosofo nel sesto de l'Etica, 'impossibile è essere savio chi non è buono,' e però non è da dire savio uomo chi con sottratti e con inganni procede, ma è da chiamare astuto; ché, sì come nullo dicerebbe savio quelli che si sapesse bene trarre de la punta d'uno coltello ne la pupilla de l'occhio, così non è da dire savio quelli che ben sa una malvagia cosa fare, la quale facendo, prima sé sempre che altrui offende." On the vice of astutia, see $l l$ Convivio, ed. G. Busnelli and G. Vandelli, 2nd ed., rev. A.E. Quaglio, Opere di Dante, ed. V. Branca et al., Vols. 4-5 (Florence, 1964), Il, 340-41, ad loc. When the present paper was read in 1979, John Ahern pointed out that Ulysses' vice had been identified as astutia by Dante's medieval commentators, as will be detailed in his forthcoming article in Mediaevalia et Humanistica.

31 Inf. XXVI.19-24. Singleton translates "io stessi nol m'invidi" as "I may not grudge myself that gift"; I have replaced it with the literal translation that he gives in his commentary (p. 452). 